\title{
SEASONAL FLUCTUATIONS OF BACTERIAL POPULATION AND MICROBIAL ACTIVITY IN SOILS CULTIVATED WITH EUCALYPTUS AND PINUS
}

\author{
Everlon Cid Rigobelo하 Ely Nahas²* \\ ${ }^{1}$ UNESP/FCAV - Programa de Pós-Graduação em Microbiologia. \\ ${ }^{2}$ UNESP/FCAV - Depto. de Produção Vegetal, Rod. Prof. Paulo Donato Castellane, s.n. - 14884-900 - Jaboticabal, \\ SP - Brasil. \\ *Corresponding author <enahas@fcav.unesp.br>
}

\begin{abstract}
The accumulation and decomposition of litter in soils under forests depend on climatic and biotic conditions. This work evaluated the effect of monthly rainfall and temperature on total bacteria, and on the dehydrogenase and respiration microbial activities. The effects of organic matter, total organic $\mathrm{C}$ and soil moisture were also evaluated. Performed from April, 1999 to March, 2000 in an Eucalyptus-cultivated and Pinus-cultivated Oxisol (Typic Haplustox), the study showed that climate and the soil variables affect the total number of bacteria and the microbial activities. The highest air temperatures and rainfall intensities were found during the Summer and, consequently, all the studied variables were maximal during this period. Minimal values varied from Autumn to Winter or, for some parameters, up to Spring. A positive correlation proved the influence of the organic matter, organic $\mathrm{C}$ and soil moisture on the total bacteria and on the respiratory and dehydrogenase activities. Litter content was also higher in the Summer as compared to the Winter, but it correlated only with the total bacteria $\left(\mathrm{r}=0.52^{* * *}\right)$. However, the correlation between the litter content and organic matter $\left(r=0.64^{* * *}\right)$ and soil moisture $\left(r=0.49^{* * *}\right)$ suggest that the soil organic matter may have influenced microbial activity. All variables found in the Eucalyptus soil were higher than that of Pinus soil, probably favored by the best soil fertility and higher $\mathrm{pH}$ value.
\end{abstract}

Key words: MPN, dehydrogenase, microbial respiration, litter, temperature

\section{FLUTUAÇÃO SAZONAL DA COMUNIDADE BACTERIANA E DA ATIVIDADE MICROBIANA EM SOLOS SOB EUCALIPTO E PINUS}

RESUMO: O acúmulo e decomposição da serapilheira em solos de florestas dependem das condições climáticas e bióticas. Este trabalho avaliou as variações mensais no número de bactérias totais e nas atividades da desidrogenase e da respiração microbiana, relacionando-as à quantidade de serapilheira depositada e aos teores de matéria orgânica e de água do solo. O estudo foi realizado de abril de 1999 a março de $2000 \mathrm{em}$ um Latossolo Vermelho-Escuro plantado com eucalipto e com Pinus. Houve influência do clima e das variáveis do solo nas bactérias totais e a atividade microbiana. Todas as variáveis ajustaram-se a equações de $3^{\circ}$ grau. Durante o verão, foram obtidos os maiores valores de temperatura e de chuvas e, consequentemente, todas as variáveis estudadas apresentaram seus valores máximos neste período, e os valores mínimos no outonoinverno ou, para alguns parâmetros, até mesmo na primavera. A correlação positiva comprovou a influência da matéria orgânica e da água do solo no número de bactérias e nas atividades respiratórias e da desidrogenase. O teor de serapilheira sobre o solo também foi maior no verão do que no inverno, mas só apresentou correlação com as contagens de bactérias $\left(r=0,52^{* * *}\right)$. Contudo, a correlação entre os teores de serapilheira e os de matéria orgânica $\left(r=0,64^{* * *}\right)$ e de água do solo $\left(r=0,49^{* * *}\right)$ demonstra que a matéria orgânica pode ter influenciado a atividade microbiana. Todas as variáveis analisadas no solo de eucalipto foram maiores do que no de Pinus, provavelmente favorecidas pela melhor fertilidade e maior valor do $\mathrm{pH}$.

Palavras-chave: NMP, desidrogenase, respiração microbiana, serapilheira, temperatura

\section{INTRODUCTION}

Major amount of forest soil organic matter is derived from the vegetation that is partly disposed on the soil surface as an organic layer (litter) and partly distributed into the soil (Klein, 2000; Santa Regina \& Tarazona, 2001). Dames et al. (1998) reported annual litter production of 3.64 to $5.89 \mathrm{t} \mathrm{ha}^{-1}$ in a Pinus patula forest in South
Africa. The most important nutrient supply to the forest is derived from litter decomposition by action of organisms under conditions of high air temperature and soil moisture. The chemical elements present in the litter are mobilized and reabsorbed by plant roots, restarting a new plant nutrient cycling and guaranteeing perennial conditions to the system (Guo \& Sims, 1999b), even in cases of low fertile soils. 
The main factors that control the organic matter transformation process are: the quantity and quality of litter material components, the physical and chemical environment, and the decomposition organisms (Swift et al., 1979). Laboratory experiments have evidenced that some environment factors, like soil water content and air temperature, affect the organic matter decomposition rate, which is usually higher in tropical than in temperate regions (Taylor \& Parkinson, 1988). In Europe, the litter decomposition rate of Pinus was positively related to the average annual temperature and pluviosity (Pausas, 1997). In the subtropical Australia, reduction below $80 \%$ on eucalyptus forest litter humidity, caused a decrease in microbial respiratory activity (O'Connell, 1990).

Among the soil organisms, the bacteria and fungi present the highest values of biomass and respiratory metabolism, and have greater participation in the organic matter decomposition process (Persson et al., 1980). The bacteria represent the major group, responsible for 25 to $30 \%$ of the total soil microbial biomass. Increases in the bacterial community during the summer have been attributed to increases in air temperature (Chhonkar \& Tarafdar, 1984); however, decreases on fungi and increases on bacteria relative quantities, respectively, were observed with increasing soil fertility (Pennanen et al., 1999). In India, records on the number of soil bacteria from several forests were higher in September and lower in July, probably because of the rain and temperature regimes (Jha et al., 1992).

The bacterial community, the microbial respiratory activity, and specific soil chemical compounds may, together, indicate the transformation evolution occurring in soils under specific forest litters (Luizão et al., 1992). The soil microbial enzyme activity is affected by edaphic and climatic factors (Jha et al., 1992). For example, in Indonesia, a study demonstrated that the dehydrogenase activity was positively correlated with soil moisture and N concentrations (Gunadi et al., 1998). However, contrarily to this result, no variation was observed in the dehydrogenase and cellulase activities for Pinus litter (Faber et al., 1992). Other factors have been related to the litter decomposition process: Schneider et al. (2000) showed that the acid phosphatase activity was dependent on the total organic C, N and the amount of soil litter found in Quercus pyrenaica and Pinus pinaster soils from Spain.

Neverthless, there is little information on the fluctuations of bacterial community and soil microbial activity in response to the climatic variations in eucalyptus and Pinus forests. The objective of this research was to evaluate the effects of seasonal climate and litter variations on the soil bacterial community and soil microbial activity, the main agents for the soil organic matter mineralization under eucalyptus and Pinus forests established on Oxisols.

\section{MATERIAL AND METHODS}

The experiment was carried out in Jaboticabal, SP, Brazil (21 ${ }^{\circ} 17^{\prime} 05^{\prime}$ 'S; 48 $17^{\circ} 09^{\prime \prime} \mathrm{W}$; altitude $\left.590 \mathrm{~m}\right)$; monthly air temperature and rainfall distribution are presented in Figure 1. The woodland areas are established on a Typic Haplustox, medium texture, an acid and low fertility soil (Table 1). The Eucalyptus spp. woodland is part of a reforested area, planted during February 1969 , in a 3 x 2 m spacing, with several native and exotic species, each species grouped in seven row plots with nine plants in each plot. The Pinus spp. woodland was planted in March 1975, in a 3 x 2 m spacing, being part of an experiment related to species and variety competition.

The areas under eucalyptus and Pinus ( 2 ha each) were split in six subareas of similar size (around 3,000 $\mathrm{m}^{2}$ ). From each subarea, sixteen randomized, simple soil subsamples were collected, grouped and homogenized, resulting in one composite sample. Six composite samples were obtained from each area. The soil samples collected from the $0-20 \mathrm{~cm}$ soil layer, after litter removal, were

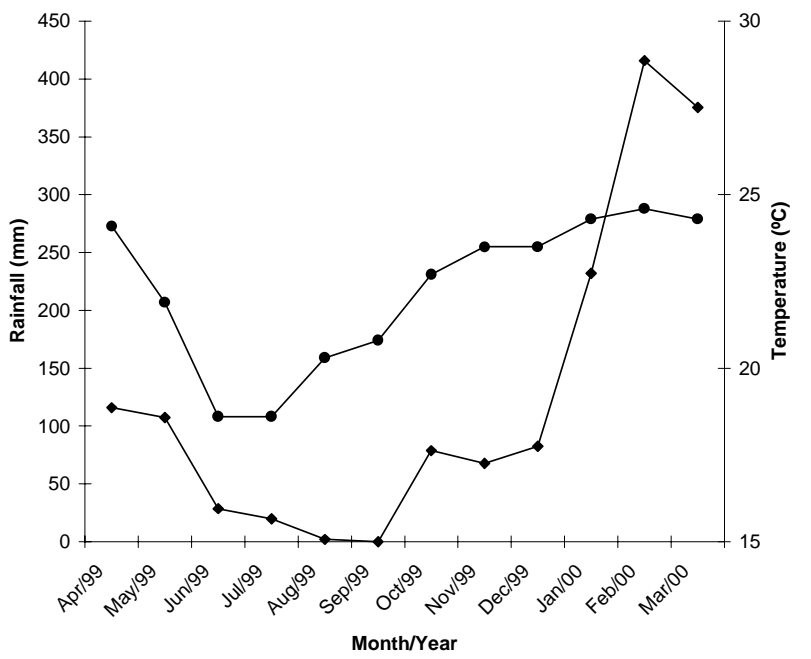

Figure 1 - Monthly variation in rainfall $(\bullet)$ and air temperature $(\bullet)$ monitored at Jaboticabal, SP, Brazil.

Table 1 - Chemical properties of the soils grown with Eucalyptus and Pinus.

\begin{tabular}{lcc}
\hline & Eucalyptus & Pinus \\
\hline $\mathrm{pH}$ & 5.3 & 4.6 \\
Organic matter $\left(\mathrm{g} \mathrm{dm}^{-3}\right)$ & 38 & 27 \\
P resin $\left(\mathrm{mg} \mathrm{dm}^{-3}\right)$ & 21 & 12 \\
$\mathrm{~K}^{+}\left(\mathrm{mmol}_{\mathrm{c}} \mathrm{dm}^{-3}\right)$ & 1.8 & 1.1 \\
$\mathrm{Ca}^{2+}\left(\mathrm{mmol}_{\mathrm{c}} \mathrm{dm}^{-3}\right)$ & 45 & 20 \\
$\mathrm{Mg}^{2+}\left(\mathrm{mmol}_{\mathrm{c}} \mathrm{dm}^{-3}\right)$ & 13 & 7 \\
$\mathrm{H}^{+}+\mathrm{Al}^{3+}\left(\mathrm{mmol}_{\mathrm{c}} \mathrm{dm}^{-3}\right)$ & 34 & 47 \\
$\mathrm{Sum}_{\mathrm{a}}$ of bases $\left(\mathrm{mmol}_{\mathrm{c}} \mathrm{dm}^{-3}\right)$ & 59.8 & 28.1 \\
$\mathrm{Cation}$ exchange capacity $\left(\mathrm{mmol}_{\mathrm{c}} \mathrm{dm}^{-3}\right)$ & 93.8 & 75.1 \\
Soil base saturation $(\%)$ & 64 & 37 \\
\hline
\end{tabular}


cleaned from pieces of leaves, stalks and roots, split in two subsamples, one of which was stored in a refrigerator for microbiological analysis and the other, oven dried at $50^{\circ} \mathrm{C}$ for chemical analysis.

For the determination of the most probable number (MPN) of total soil bacteria (Alexander, 1982), 2.7 $\mathrm{mL}$ of the Bunt \& Rovira (1955) culture medium were transferred to each well of a 24 -well plate. A soil suspension was prepared by shaking $10 \mathrm{~g}$ of moist soil into $95 \mathrm{~mL}$ of a $0.1 \%$ pyrophosphate solution $(\mathrm{m} / \mathrm{v})$ during 30 minutes; a $10^{-3}$ serial dilution of the soil suspension was made in test tubes. Thereafter a $0.3 \mathrm{~mL}$ aliquot sample was transferred to each of the four wells of the first plate row. After homogenization, a $0.3 \mathrm{~mL}$ aliquot sample was taken from each well of the first row and transferred to the following one in the second row, and so successively, until a $10^{-9}$ suspension dilution. The plates were incubated at $30^{\circ} \mathrm{C}$ for 24 hours. The wells presenting bacterial growth presented turbidity, and the minimal turbidity was considered a positive result. The positive results of the last three series of wells were considered for bacterial counting.

The respiratory activity was determined according to Jenkinson \& Powlson (1976), by transferring 100 g-fresh-collected soil sample into $2,500 \mathrm{~mL}$ recipients, which were incubated at $30^{\circ} \mathrm{C}$ for one week. The dehydrogenase activity was determined according to Casida Jr. (1977) in soil extracts obtained after incubation of 3 $\mathrm{g}$ of dried soil at $37^{\circ} \mathrm{C}$ for 24 hours, and then addition of $30 \mathrm{~mL}$ methanol. After filtration, the absorbances were read in spectrophotometer at the $485 \mathrm{~nm}$ wavelength. One unit of enzyme activity corresponded to the quantity of enzyme producing $1.0 \mu \mathrm{g}$ triphenylformazan from $1.0 \mathrm{~g}$ dry soil per three hours.

Total organic carbon was determined according to Sims \& Haby (1971), using $1.0 \mathrm{~g}$, dried soil sample. The soil $\mathrm{pH}$ was determined in $0.01 \mathrm{~mol} \mathrm{~L}^{-1} \mathrm{CaCl}_{2}$ solution (1:2.5). Soil moisture was determined by oven drying the soil samples at $105^{\circ} \mathrm{C}$ for 24 hours. Organic matter was determined after soil sample furnace incineration at $550^{\circ} \mathrm{C}$ for 24 hours.
Monthly, litterfall samples were collected from inside a $0.25 \mathrm{~m}^{2}$ gauge and the fresh and dry weights were determined. The litterfall samples were dried in a forced air oven at $105^{\circ} \mathrm{C}$ for three days before dry matter determinations.

A split-plot experimental design was used with main plots being the two types of litter and the sub-plots, the monthly collected litterfall samples. The most probable number of total bacteria (MPN) was evaluated by a computer program (Hurley \& Roscoe, 1983). For the analysis of variance, MPN values were transformed into $\log (\mathrm{X}+$ 1 ), where $X=N M P g^{-1}$ dried soil. Mean comparisons were made according to the Tukey test $(P=0.05)$. Correlation between variables and regression analysis of the time dependent variables were also calculated. All the statistical analysis were performed using SAS (1990).

\section{RESULTS AND DISCUSSION}

All variables showed fluctuations over time, statistically adjusted to third degree equations, possibly due to variations in the climatic variables. Monthly variation of the soil bacterial number under eucalyptus and Pinus followed the variation trend observed in the respiratory and dehydrogenase activities (Figure 2). From June to September, months with lower rainfall and air temperature (Figure 1), the bacterial community numbers decreased (Figure $2 \mathrm{~A}$ ), also followed by a decrease in the respiratory (Figure 2B) and dehydrogenase activities (Figure 2C). During the warmer and moister months, December to March, the bacterial number decreased followed by an increase in the microbial activities (Figure 2 B,C). Consequently, correlations between the bacterial counting and $\mathrm{CO}_{2}$ evolution $\left(\mathrm{r}=0.50^{* * *}\right)$, and between this latter variable and dehydrogenase activity $\left(r=0.47^{* *}\right)$ were found. No correlation was observed between the number of bacteria and dehydrogenase activity, possibly because of the low microbial activity in the Pinus soil. In the eucalyptus soil, the dehydrogenase activity increased seven fold from the minimal (October) to the maximal (December) activity, which coincided with the higher bacteria numbers.

Table 2 - Correlation coefficients (r) between selected variables including data of the Eucalyptus and Pinus soils.

\begin{tabular}{|c|c|c|c|c|c|c|c|}
\hline & Bacteria & Dehydrogenase & Organic $\mathrm{C}$ & $\begin{array}{l}\text { Organic } \\
\text { matter }\end{array}$ & $\begin{array}{c}\text { Soil } \\
\text { moisture }\end{array}$ & $\mathrm{pH}$ & $\begin{array}{c}\text { Litter } \\
\text { production }\end{array}$ \\
\hline $\mathrm{CO}_{2}$ production & $0.50 * * *$ & $0.47 * *$ & $0.68 * * *$ & $0.48 * * *$ & $0.51 * * *$ & $0.25^{\mathrm{NS}}$ & $0.36^{\mathrm{NS}}$ \\
\hline Bacteria & - & $0.01^{\mathrm{NS}}$ & $0.43 * *$ & $0.51 * * *$ & $0.72 * * *$ & $0.13^{\mathrm{NS}}$ & $0.52 * * *$ \\
\hline Dehydrogenase & - & - & $0.65 * * *$ & $0.59 * * *$ & $0.36^{\mathrm{NS}}$ & $0.49 * *$ & $0.15^{\mathrm{NS}}$ \\
\hline Organic carbon & - & - & - & $0.64 * * *$ & $0.30^{\mathrm{NS}}$ & $0.62 * * *$ & $0.05^{\mathrm{NS}}$ \\
\hline Organic matter & - & - & - & - & $0.59 * * *$ & $0.79 * * *$ & $0.64 * * *$ \\
\hline Soil moisture & - & - & - & - & - & $0.16^{\mathrm{NS}}$ & $0.49 * *$ \\
\hline $\mathrm{pH}$ & - & - & - & - & - & - & $0.32^{\mathrm{NS}}$ \\
\hline
\end{tabular}

${ }^{\mathrm{NS}}$ not significant; $* * *$, significant at $P<0.01$ and $P<0.001$, respectively. $\mathrm{N}=144$. 
The bacterial community numbers increased 54 and 65 times for the eucalyptus and Pinus soils, respectively (Figure 2A) from the dry and chilly period to the warmer and rainy period, that is from September to January. The fluctuations in the number of bacteria agree with the results obtained by Clarholm \& Rosswall (1980) in a Pinus forest, although there was only a 10 -fold increase in the bacteria numbers, possibly because of the lower air temperatures.

Maximal microbial respiratory activity was observed from December/1999 to January-February/2000, as compared to other months (Figure $2 \mathrm{~B}$ ). $\mathrm{CO}_{2}$ evolution increased three to four fold from the driest to the most humid month, and was correlated with the soil moisture content $\left(\mathrm{r}=0.51^{* * *}\right)$. In an eucalyptus soil from Australia, there was a 2-fold increase in $\mathrm{CO}_{2}$ evolution, corre-

(A)

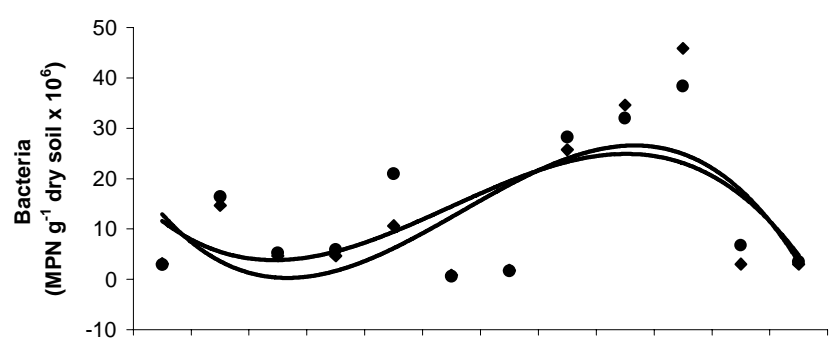

(B)

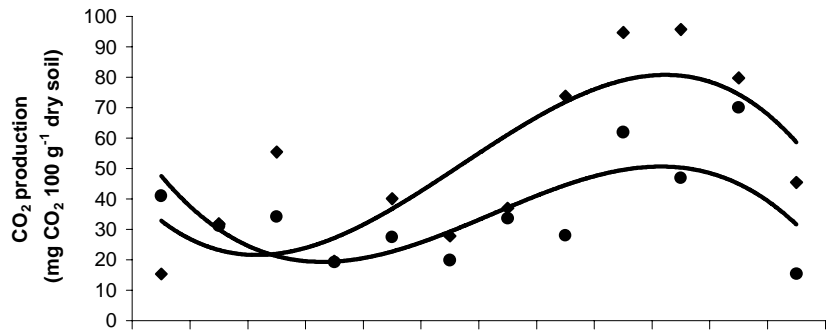

(C)

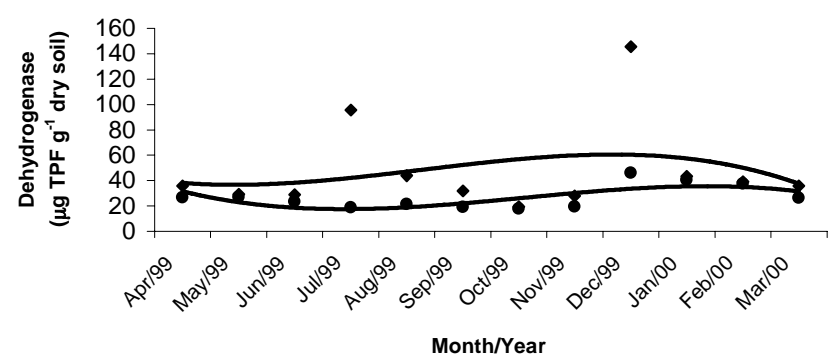

Figure 2 - Monthly variation in bacterial population (A), $\mathrm{CO}_{2}$ production (B) and dehydrogenase activity (C) in Eucalyptus $(\bullet)$ and Pinus $(\bullet)$ soils. (TPF, triphenylformazan; MPN, most probable number). $F$ test, Bacteria: Species $(\mathrm{S})=0.8^{\mathrm{NS}}$, Time $(\mathrm{T})=4.2^{* *}, \mathrm{~S}$ $\mathrm{x} \mathrm{T}=0.6^{\mathrm{NS}} ; \mathrm{CO}_{2}$ production: $\mathrm{S}=73.9^{* *}, \mathrm{~T}=93.5^{* *}, \mathrm{~S}$ x T = 4.1*; Dehydrogenase: $\mathrm{S}=118.3^{*}, \mathrm{~T}=21.0^{*}, \mathrm{~S}$ x $\mathrm{T}=14.2 *$ NS, not significant; $* * *$, significant at $P<0.05$ and $P<0.01$, respectively. lated with soil temperature and moisture during the moist season (Chen et al., 2002). In a Pinus soil, Fang et al. (1998) attributed the increase in $\mathrm{CO}_{2}$ evolution to the increase in root biomass, soil litter and humus contents. However, $\mathrm{CO}_{2}$ evolution was inversely correlated to the soil organic matter content. Although no correlation was observed between the respiratory activity and the litter quantity accumulated in the soil (Table 2), positive correlations between soil organic matter content and respiratory activity $\left(r=0.48^{* * * *}\right)$ and litter content $\left(r=0.64^{* * * *}\right)$ were observed.

The greater litter accumulation observed during the moisty season (Figure 3) can be attributed to the greater rainfall and consequently to the increase in the vegetal biomass. The influence of the soil moisture on the litter production was evidenced by the correlation found between these two variables $\left(r=0.49^{* *}\right)$. In Australia, Grigg \& Mulligan (1999) observed that the decrease in the litter production in two eucalyptus forests occurred when the rainfall amount also decreased. Meanwhile, in New Zealand, Guo \& Sims (1999a) found out that 70 to $80 \%$ of the total annual litter production was formed during the summer, what was also observed in an Eucalyptus tereticornis forest in India (Bahar et al., 2001).

Seasonally-variable environmental factors, like air temperature and soil moisture, may influence the soil microbial community and activity and control the organic matter decomposition process (Maire et al., 1999). Higher decomposition rates in eucalyptus tropical forests were related to rainfall, soil moisture and temperature (Virzo de Santo et al., 1993; Pande, 1999). The higher litterfall during the rainy season, for both Pinus and eucalyptus, associated to the increase in the soil moisture content

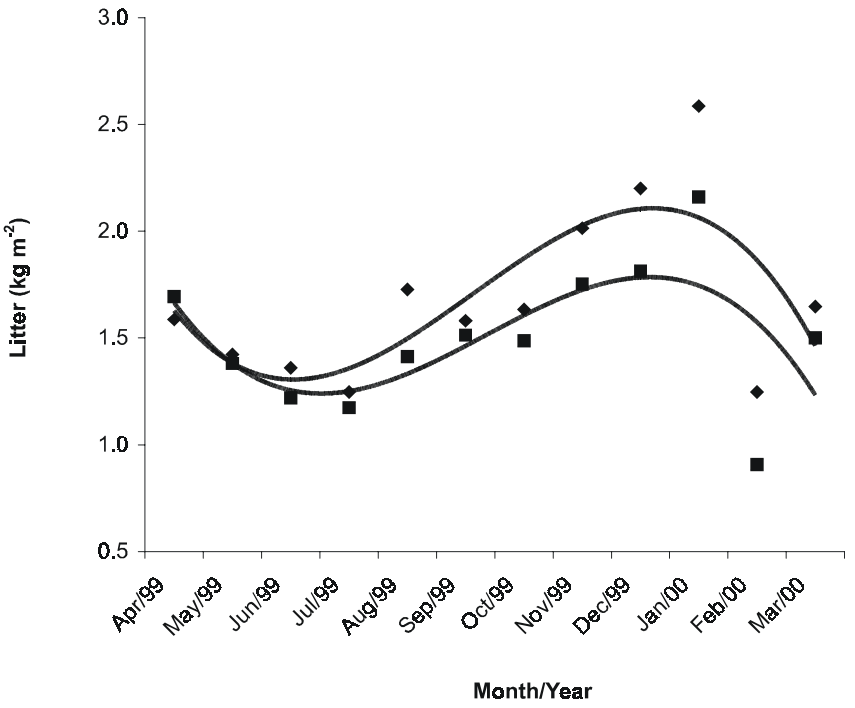

Figure 3 - Monthly variation in litterfall in Eucalyptus $(\bullet)$ and Pinus $(\bullet)$ soils. $F$-test, Species $(\mathrm{S})=16.7^{* *}$, Time $(\mathrm{T})=20.6^{* *}$, $\mathrm{S} \times \mathrm{T}=1.0^{\mathrm{NS}}$. NS, not significant; $* *$, significant $P<0.01$ 
(Figure 4A) and to the air temperature (Figure 1), might have contributed to the increase in the soil organic matter (Figure 4B) and organic carbon contents (Figure 4C), as consequence of the increase in the litter decomposition.

Dilly \& Munch (1996) reported a lower decomposition rate in Alnus glutinosa, during the summer, when the litter moisture content was lower, contrarily to the results obtained in this research. However, results herein found for Pinus and eucalyptus soils, may be corroborated by the correlation found between the bacterial number and the litterfall $\left(r=0.52^{* * * *}\right)$, and bacterial number and the increase in the organic carbon content $\left(r=0.43^{* * *}\right)$ derived from the organic matter mineralization. The increase in the bacterial number and in the microorganism activity resulted, probably, from the organic matter accumulation (Figure 4B), which was positively correlated to the bacteria number $\left(\mathrm{r}=0.51^{* * *}\right)$, to the respiratory activity $(\mathrm{r}=$ $\left.0.48^{* * * *}\right)$ and to the dehydrogenase activity $\left(\mathrm{r}=0.59^{* * * *}\right)$ (Table 2). The increase in the microbial biomass $\mathrm{C}$ might

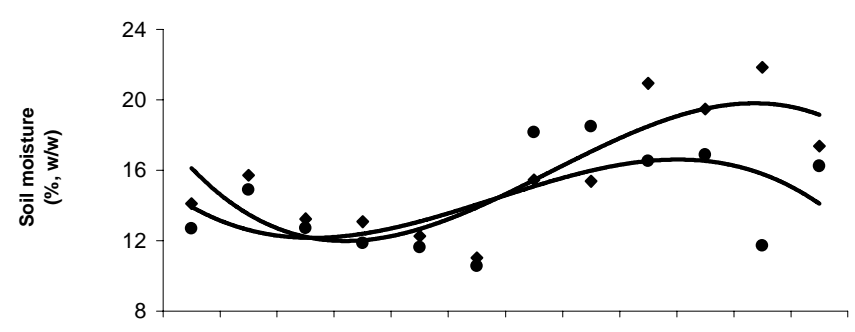

(B)

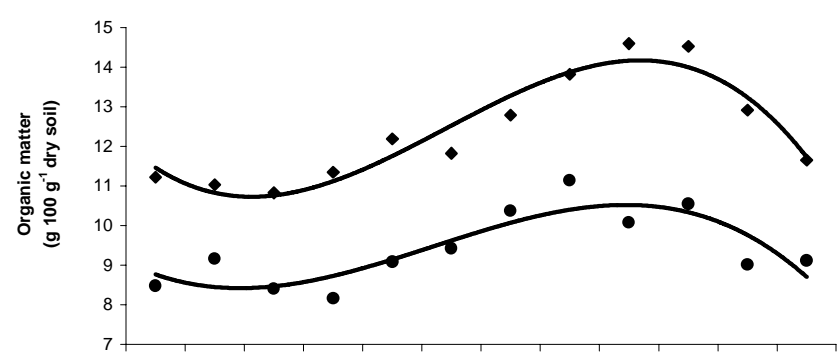

(C)

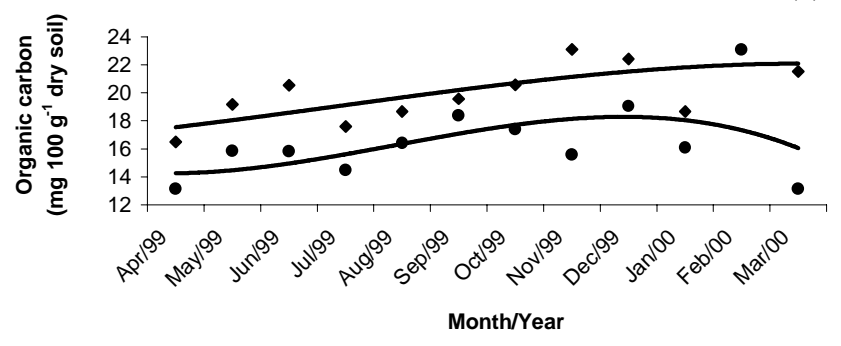

Figure 4 - Monthly variation in soil moisture (A), organic matter (B) and organic carbon (C) in Eucalyptus ( $\bullet$ ) and Pinus $(\bullet)$ soils. $F$-test, Organic matter: Species $(\mathrm{S})=89.3^{* *}$, Time $(\mathrm{T})=3.9^{* *}, \mathrm{~S} \times \mathrm{T}=0.5^{\mathrm{NS}}$; Organic carbon: $\mathrm{S}=$ $33.1^{* *}, \mathrm{~T}=4.2^{* *}, \mathrm{~S} \times \mathrm{T}=1.0^{\mathrm{Ns}}$; Soil moisture: $\mathrm{S}=$ $9.1 * *, \mathrm{~T}=10.0^{* *}, \mathrm{~S} \times \mathrm{T}=4.1 * * . \mathrm{NS}$, not significant; ** significant at $P<0.01$. have resulted from the increase in the soil organic C (McGill et al., 1986; Anderson \& Domsch, 1989). Nohrstedt (1985) have also concluded that the soil organic $\mathrm{C}$ from several forests was the factor influencing microbial activity.

Except for the bacterial numbers, similar in both eucalyptus and Pinus soils, data obtained for the other variables were higher for the eucalyptus soil than for the Pinus soil (Figures 2, 3 and 4). The quantity and moisture of litterfall might have affected the results, because litter accumulation was significantly higher for eucalyptus $\left(1.69 \mathrm{~kg} \mathrm{~m}^{-2}\right)$ than for Pinus $\left(1.50 \mathrm{~kg} \mathrm{~m}^{-2}\right)$ (Figure 3), and with moisture contents of $18 \%$ and $17 \%$ (data not shown), respectively. On the other hand, the eucalyptus soil had higher fertility and $\mathrm{pH}$ than the Pinus soil (Table 1 ), which might have caused an increase in the microbial activity and in the litter decomposition processes in the first one.

\section{ACKNOWLEDGMENTS}

\section{To FAPESP and CNPq for fellowships. \\ REFERENCES}

ALEXANDER, M. Most probable number method for microbial populations. In: PAGE, A. L; MILLER, R.H.; KEENEY, D.R. (Ed.) Methods of soil analysis: Part 2. Chemical and microbiological properties. 2.ed. Madison: ASA, 1982. p.815-820.

ANDERSON, T.H.; DOMSCH, K.H. Ratios of microbial biomass to total organic carbon in arable soils. Soil Biology and Biochemistry, v.21, p.471-479, 1989.

BAHAR, N.; KAPOOR, K.S.; JAIN, A.K. Litter production pattern of Eucalyptus tereticornis plantation in protected and unprotected areas of upper Gangetic plain. Indian Forester, v.127, p.814-820, 2001.

BUNT, J.S.; ROVIRA, A.D. Microbiological studies of some subantartic soils. Journal of Soil Science, v.6, p.119-128, 1955.

CASIDA JR., L.E. Microbial metabolic activity in soil as measured by dehydrogenase determinations. Applied and Environmental Microbiology, v.34, p.630-636, 1977.

CHEN, X.; EAMUS, D.; HUTLEY, L.B. Seasonal patterns of soil carbon dioxide efflux from a wet-dry tropical savanna of northern Australia. Australian Journal of Botany, v.50, p.43-51, 2002.

CHHONKAR, P.K.; TARAFDAR, J.C. Accumulation of phosphatases in soil. Journal of Indian Society of Soil Science, v.132, p.266-272, 1984.

CLARHOLM, M.; ROSSWALL, T. Biomass and turnover of bacteria in a forest soil and a peat. Soil Biology and Biochemistry, v.12, p.49-57, 1980.

DAMES, J.F.; SCHOLES, M.C.; STRAKER, C.J. Litter production and accumulation in Pinus patula plantations of the Mpumalanga Province, South Africa. Plant and Soil, v.2, p.183-190, 1998.

DILLY, O.; MUNCH, J.C. Microbial biomass content, basal respiration and enzyme activities during the course of decomposition of leaf litter in a black alder (Alnus glutinosa (L.) Gaertn.) forest. Soil Biology and Biochemistry, v.28, p.1073-1081, 1996.

FABER, J.H.; TEUBEN, A.; BERG, M.P.; DOELMAN, P. Microbial biomass and activity in pine litter in the presence of Tomocerus minor (Insecta Collembola). Biology and Fertility of Soils, v.12, p.233-240, 1992.

FANG. C.; MONCRIEFF, J.B.; GHOLZ, H.L.; CLARK, K.L. Soil $\mathrm{CO}_{2}$ efflux and its spatial variation in a Florida slash pine plantation. Plant and Soil, v.205, p.135-146, 1998.

GRIGG, A.H.; MULLIGAN, D.R. Litterfall from two eucalypt woodlands in central Queensland. Australian Journal of Ecology, v.24, p.662664, 1999. 
GUNADI, B.; VERHOEF, H.A.; BEDAUX, J.J.M. Seasonal dynamics of decomposition of coniferous leaf litter in a forest plantation (Pinus merkusii) in Central Java, Indonesia. Soil Biology and Biochemistry, v.30, p.845-852, 1998.

GUO, L.B.; SIMS, R.E.H. Litter decomposition and nutrient release via litter decomposition in New Zealand eucalypt short rotation forests. Agriculture, Ecosystems and Environment, v.75, p.133-140, 1999a.

GUO, L.B.; SIMS, R.E.H. Litter production and nutrient return in New Zealand eucalypt short-rotation forests: implications for land management. Agriculture, Ecosystems and Environment, v.73, p.93$100,1999 b$

HURLEY, M.A.; ROSCOE, M.E. Automated statistical analysis of microbial enumeration by dilutions series. Journal of Applied Bacteriology, v.55, p.159-164, 1983.

JENKINSON, D.S.; POWLSON, D.S. The effects of biocidal treatments on metabolism in soil-V. A method for measuring soil biomass. Soil Biology and Biochemistry, v.8, p.209-213, 1976.

JHA, D.K.; SHARMA, G.D.; MISHRA, R.R. Soil microbial population numbers and enzyme activities in relation to altitude and forest degradation. Soil Biology and Biochemistry, v.24, p.761-767, 1992.

KLEIN D.A. The rhizosphere. In: LEDERBERG, J. (Ed.) Encyclopedia of microbiology. 2.ed. San Diego: Academic Press, 2000. v.4, p.117126.

LUIZÃO, R.C.; BONDE, T.A.; ROSSWALL, T. Seasonal variation of soil microbial biomass - the effects of clearfelling a tropical rainforest and establishment of pasture in the Central Amazon. Soil Biology and Biochemistry, v.24, p.805-813, 1992

MAIRE, N.; BORCARD, D.; LACZKÓ, E.; MATTHEY, W. Organic matter cycling in grassland soils of the Swiss Jura mountains: biodiversity and strategies of the living communities. Soil Biology and Biochemistry, v.31, p.1281-1293,1999.

McGILL, W.B.; CANNON, K.R.; ROBERTSON, J.A.; COOK, F.D. Dynamics of soil microbial biomass and water-soluble organic $\mathrm{C}$ in Breton $\mathrm{L}$ after 50 years of cropping to two rotations. Canadian Journal of Soil Science, v.66, p.1-19, 1986.

NOHRSTEDT, H-Ö. Biological activity in soil from forest stands in Central Sweden, as related to site properties. Microbial Ecology, v.11, p.259266,1985

O'CONNELL, A.M. Microbial decomposition (respiration) of litter in eucalypt forest of south-western Australia: an empirical model based on laboratory incubations. Soil Biology and Biochemistry, v.22, p.153160,1990
PANDE, P.K. Litter decomposition in tropical plantations: impact of climate and substrate quality. Indian Forester, v.125, p.599-608, 1999.

PAUSAS, J.G. Litter fall and litter decomposition in Pinus sylvestris forests of the eastern Pyrenees. Journal of Vegetation Science, v.8, p.643650, 1997.

PENNANEN, T.; LISKI, J.; BÁÁTH, E.; KITUNEN, V.; UOTILA, J.; WESTMAN, C. J.; FRITZE, H. Structure of the microbial communities in coniferous forest soils in relation to site fertility and stand development stage. Microbial Ecology, v.38, p.168-179, 1999.

PERSSON, T.; BAATH, E.; CLARHOLM, M.; LUNDKVIST, H.; SÖDERSTRÖM, B.; SOHLENIUS, B. Trophic structure, biomass dynamics and carbon metabolism of soil organisms in a Scots pine forest. Ecological Bulletins, v.32, p.419-459, 1980.

SANTA REGINA, I.; TARAZONA, T. Nutrient pools to the soil through organic matter and throughfall under a Scots pine plantation in the Sierra de la Demanda, Spain. European Journal of Soil Biology, v.37, p.125133, 2001.

SAS INSTITUTE. SAS/STAT use's guide (Version 6). 3.ed. Cary: SAS Institute, 1990. 705p.

SCHNEIDER, K.; TURRION, M.B.; GALLARDO, J.F. Modified method for measuring acid phosphatase activities in forest soils with high organic matter content. Communications in Soil Science and Plant Analysis, v.31, p.3077-3088, 2000.

SIMS, J.R.; HABY, V.A. Simplified colorimetric determination of soil organic matter. Soil Science, v.112, p.137-141, 1971

SWIFT, M.J.; HEAL, O.W.; ANDERSON, J.M. Decomposition in terrestrial ecosystems. Oxford: Blackwell Scientific Publications, 1979. $372 \mathrm{p}$

TAYLOR, B.R.; PARKINSON, D. Aspen and pine leaf litter decomposition in laboratory microcosms. II. Interactions of temperature and moisture level. Canadian Journal of Botany, v.66, p.1966-1973, 1988.

VIRZO de SANTO, A.; BERG, B.; RUTIGLIANO, F.A.; ALFANI, A.; FIORETTO, A. Factors regulating early-stage decomposition of needle litters in five different coniferous forests. Soil Biology and Biochemistry, v.25, p.1423-1433, 1993.

Received November 18, 2002

Accepted October 23, 2003 